\title{
PAYG in an ageing society: The case of Sweden versus Germany
}

Received (in revised form): 4th November, 2006

\section{Ivonne Honekamp}

is a masters student at the Utrecht School of Economics. Her fields of study are Economics and Social Sciences. From 1996 she was employed as civil servant in the federal armed forces in Germany. In 2004, she started her German Diploma in Economics at the University of Bonn and in 2006 she continued her studies in Utrecht.

Abstract This paper assesses how two different countries deal with an ageing population threatening the stability of their pay-as-you-go pension system (PAYG). Financing pensions through the contributions of the working population was a perfect measure to meet the requirements at the time of implementation. However, economic and especially demographic circumstances have changed. The slow down in economic growth, a low birth rate and an ageing population put pressure on governments to reform their pension system. This paper provides an overview of the basic pay-as-you-go model to illustrate financial challenges to the Swedish and German pension scheme. Moreover, recent developments in the Swedish and German state pension schemes are outlined. The Swedish government decided to reform the pension system in one go in 1999 with a transition period to the new system of 16 years, while the German state pension system has experienced several reforms since 1992. An assessment of the financial stability of both schemes discusses the advantages and shortcomings of both systems. It seems as if the Swedish system is well prepared even for challenges like the retirement of the baby-boom generation while the German state pension could easily run into serious financial problems despite the reforms.

Pensions (2007) 12, 138-153. doi:10.1057/palgrave.pm.5950052

Keywords: pensions, finance, PAYG, ageing, Germany, Sweden, financial stability, Riester Pension, NDC

\section{Introduction}

Many European countries introduced the pay-asyou-go pension system (PAYG) after the Second World War. Financing pensions through the contributions of the working population was a perfect measure to meet the requirements at that time. Economic and especially demographic circumstances have however changed. The slow down in economic growth, a low birth rate and an ageing population put pressure on governments to reform their pension system. The

Correspondence: Ivonne Honekamp,

Cand. Master of Sciences in Economics \& Social Sciences,

Cand. Diplomvolkswirt, Schillerstr. 9b, Rotenburg (Wümme) 27356, Germany.

Tel: +49(0)2461 960878;

E-mail: ivo@honekamp.de aim of this paper is to asses how two different countries deal with an ageing population threatening the stability of their PAYG.

In the first part of the paper an overview of the basic pay-as-you-go model will be provided to illustrate financial challenges to the Swedish and German pension scheme. The second part of the paper will provide an impression of the developments in the Swedish state pension scheme. The Swedish Government decided to reform the pension system in one go in 1999 with a transition period to the new system of 16 years. ${ }^{1}$ This description will then be accompanied by an assessment of the new system in terms of its financial stability. In part three, the same approach will be used to investigate the German state pension system, which has experienced 
several reforms since 1992. Finally, the main differences and shortcomings of the German and Swedish pension system will be evaluated and extended by policy suggestions.

\section{Theory of the pay-as-you-go system}

Sweden and Germany have two things in common; the financing of their system is primarily based on pay-as-you-go basis and the introduction of a small funded pillar. The main challenges such a system has to cope with are an ageing population and changing economic conditions. ${ }^{2}$ For that reason the pay-as-you-go models of both countries will now be analysed in order to see if they are able to withstand these attacks. For this analysis, a model from Homburg ${ }^{3}$ will be used.

The starting point is to model a pure pay-asyou-go system and then adjust it to the individual variations in Sweden and Germany. We have an overlapping generation model, which means that each individual has two life phases, the working phase and the retirement phase, to model the pay-as-you-go financing of pensions. Hence in each time period $t$ two generations live, I will denote the working population as $N_{t}^{1}$ and the pensioners as $N_{t}^{2}$. During the working phase, people earn a wage $w_{t}$ and contribute a fraction $t_{t}$ of their income to the pension system (often $t_{t}$ is also referred to as the pay-roll tax). Thus total contributions in Period $t$ make up $N_{t}^{1} \cdot w_{t} \cdot t_{t}$ and the total expenditure on pensions is $N_{t}^{2} \cdot P_{t}$ whereby $P_{t}$ is the average pension paid to each individual. We assume that total contributions equal total expenditure, therefore ${ }^{4}$

$$
P_{t}=\frac{N_{t}^{1} \cdot w_{t} \cdot t_{t}}{N_{t}^{2}} .
$$

Due to the fact that the growth rate of the working population is $n_{t}=N_{t}^{1}-N_{t-1}^{1} / N_{t}^{1}-1$ we can rewrite Equation (1) as follows: ${ }^{5}$

$$
P_{t}=\left(1+n_{t}\right) w_{t} \cdot t_{t}
$$

Now it is possible for a state to follow one of two policies, either keeping the replacement rate or the pay-roll tax constant. Germany has long followed the first policy but is slowly switching to keep the contribution-rate constant. Why this has occurred can easily be shown with a model of a constant replacement rate.

$$
t_{t}=\frac{q}{1+n_{t}}
$$

The replacement rate $q$ is held constant over time, whereby the pay-roll tax $t_{t}$ and the growth of the labour force $n_{t}$ are allowed to vary. As can be seen from Equation (3), the approach of a constant pension-level is only practicable as long as the growth factor of the working population $\left(1+n_{t}\right)$ does not permanently decrease beyond a certain level. With declining or even negative population growth the pay-roll tax has to be increased in order to hold the pension-level constant. In the case of Germany, the labour force has declined throughout the years and hence the contribution rate has been subject to steady increases. In Figure 1 the negative relationship between labour-force participation and pay-roll taxes can be observed. Where taxes reached a peak in 1998, participation rates were in a trough.

In 2004, the German government felt that the upper limit of pay-roll taxes, which could be expected from the population, would soon be reached. Thus with the Pensions Insurance Sustainability Act, which was passed in July 2004, they decided to put an upper limit on the contribution level. Politicians determined that the pay-roll tax should not exceed 20 per cent until 2020 and 22 per cent in 2030. They also,

however, agreed on a minimum replacement rate, which is 46 per cent until 2020 and 43 per cent until 2030. This minimum replacement rate is a curiosity according to Fenge and Weizäcker ${ }^{6}$ from the Ifo-Institute in Munich, which in the long run will conflict with the upper limit of pay-roll taxes. On account of the actual policy debate surrounding pensions, they argue that the minimum replacement rate is unlikely to have an effect on contribution rates in the future.

Now the constant pay-roll tax approach will be illustrated, which has recently atrracted more attention in Germany's pension politics. In 


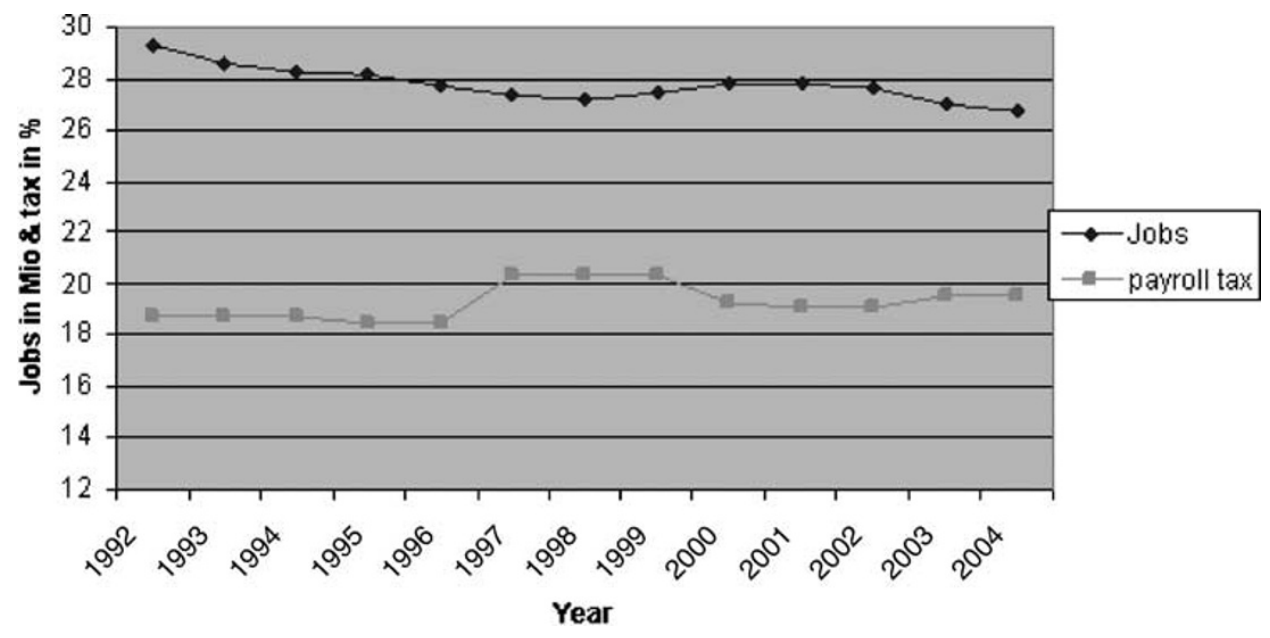

Figure 1: Jobs subject to social insurance contribution and pay-roll taxes as a percentage of income ${ }^{32}$

Sweden, this approach has been applied since the pension reform in 1999. This means that individual contributions $(t)$ remain constant while the replacement rate based on gross wages is allowed to vary, that is, $q_{t}=P_{t} / w_{t}$, after substituting (2) for $P_{t}$ we get

$$
q_{t}=\left(1+n_{t}\right) t
$$

The replacement rate is solely dependent on the growth rate of the working population. Hence a decline in the growth rate of the labour force would reduce the replacement rate. For comparisons of different pension schemes, it is important to know how the internal rent in a PAYG is composed. The internal rent is one of the measures that can be used as an indicator of the financial stability of a system. In the case of a constant pay-roll tax, the internal rent $i_{t}$ is defined through

$$
1+t_{i}=\frac{P_{t+1}}{w_{t} \cdot t_{t}} .
$$

The higher the cohort's pensions in period $t+1$ in relation to their contributions in period $t$, the higher the internal rent. It is possible to reformulate this equation to derive the internal rent in terms of labour force growth and average wage growth. For this purpose, it is important to know that the growth in the wage rate is $g_{t}=w_{t}-w_{t-1} / w_{t-1}$ and to keep in mind that contributions $t$ are fixed. Hence we derive an internal rent of

$$
1+i_{t}=\left(1+n_{t+1}\right)\left(1+g_{t+1}\right) .
$$

The rent an individual receives on his contributions to the pension scheme depends on the growth rate of the wage bill $\left[\left(1+n_{t+1}\right)\left(1+g_{t+1}\right)\right]$. People should care about their own fertility decisions because it influences their internal rent on contributions. The German pension formula comes close to the theoretical internal rate of return of the pay-as-you-go system. It links benefits at retirement to the current wage level thereby taking account of $g$, and since the 'Rentenversicherungs-Nachhaltigkeitsgesetz' from July 2004 there is also a sustainability factor ${ }^{7}$ included to take account of $n$.

The implicit return of the pay-as-you-go system $\left(g_{t+1}+n_{t+1}\right)$, the growth rate of the wage bill, is also the natural rate of return for a notional defined contribution system (NDC) as introduced by Sweden in 1999. Nevertheless, Sweden has chosen a different rate of return, which is the average wage growth $g_{t}+1$. Hence they do not account for demography when determining the internal rate of return. As a result, the rate of return in the NDC is greater than in the classical PAYG 


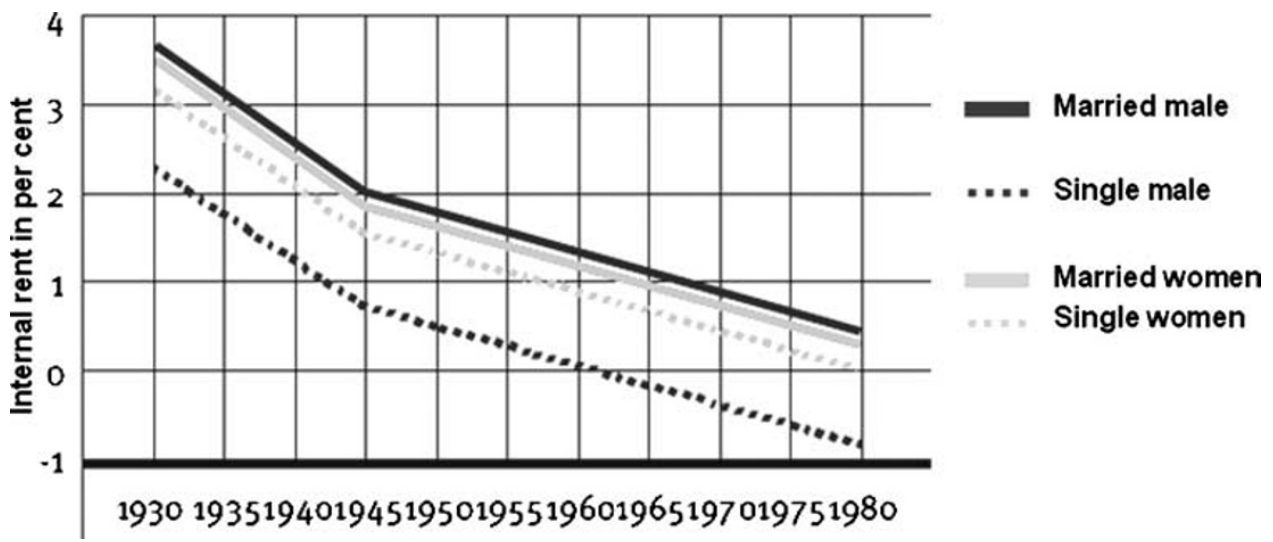

Figure 2: Internal-rent on contributions in Germany for birth cohorts $1930-1980^{33}$

because with an ageing population $\left(g_{t+1}+n_{t+1}\right)$ is smaller than $g_{t+1}$ because $n_{t+1}$ is negative (Figure 2).

The graph shows a steady decrease of the internal rent, for the cohort born in 1980 it is almost zero. Hence it seems reasonable that $\left(g_{t+1}+n_{t+1}\right)$ is smaller than $r$, the interest earned on the capital market. One could ask why not switch to a funded system, if the interest does exceed the internal rent. There are many reasons why a complete transition may not be worthwhile. First, saving for old age on the capital market bears the risk of unexpected shocks and inflation. Secondly, either one generation has to cope with a double burden, ${ }^{8}$ which the Government can not expect of the people, or the state has to pay the pensions by public debt. The public debt option would not improve the overall situation to gain from higher interest rates on the capital market because the interest received on contributions is unlikely to outweigh the interest the state has to pay for the debt. There may be more reasons why countries stick to their pay-asyou-go system, which are founded in the roots of the individual welfare states.

Nevertheless, Sweden and Germany are going to reduce the importance of the first pillar of their pension scheme slowly. This is important in the long-run; as can be seen from (3) and (4), the negative population growth will sooner or later cause the replacement rate to fall beyond a certain level or increase the contribution rate above the threshold.
How the pension systems look like in more detail and how they back up the PAYG with a funded pillar will be considered in the next part.

\section{The state pension system in Sweden}

\section{Features of the pension system today}

\section{Why a reform?}

The Swedish government had three major reasons to reform their state pension system. The first was the financial instability of the system. Pension rates were indexed to prices rather than to wages. This is a problem in times of low or even negative productivity growth, because Pensions tend to rise faster than wages. This inevitably leads to increasing pay-roll taxes to finance mounting pension payments. Projections from the early 1990s also show that the buffer funds designed to intervene in such a situation would have been exhausted within $20-25$ years. ${ }^{1}$ The second reason was the unfair redistribution of income from people on low income, which scarcely increased during their working life to more educated people who entered the labour force later but experienced a sharp increase in wages throughout their work histories. This inequity was caused by the rule that pension payments were based on the 15 years of highest earnings and not on individual contributions. Finally, the pension system led to significant work 
disincentives. There was no reason for people to extend their working life because their Pension entitlements would not increase despite paying additional contributions.

The Swedish pension system consists of three pillars, the state pension, the occupational pension and additional private savings. During the reform process in the 1990s, the Swedish government decided to split the state pension system into three parts. This is the notional NDC, supported through a funded pillar, the Premium-Pension and a guarantee pension for people who are not able to earn adequate pension rights.

\section{Notional-Defined-Contribution (NDC)}

The Notional-Defined-Contribution system (NDC) makes up the largest part of the three. It is an income-based pension system that is mainly financed on a PAYG basis. The overall contribution rate is 18.5 per cent of the pension base, ${ }^{9}$ which is split between employee and employer. Individual contributions to the NDC constitute 16 per cent of the pension base, which are recorded in fictitious individual accounts.

Every Swedish krona paid in to the system results in an equivalent pension entitlement after the so-called life-income principle. ${ }^{10}$ With this innovation in the pension system, the Government was able to abolish two big problems of the previous pension system. First, there is no redistribution from the low-wage earners to the high-wage earners, since pensions are now based on lifetime income and not on the 15 years of highest earnings. Secondly, work disincentives are minimised since each year of additional work adds to the pension entitlements and the retirement age is flexible.

The growth of the pension balance on the notional account is influenced by three factors. These factors are taken into account each year when the pension balance is recalculated. First, the pension balance of those who have died before reaching the age of retirement is distributed among survivors born in the same year (survivor's bonus). From the age of 60 the pension balance is instead adjusted upward by an estimated survivor's bonus factor, which is based on life expectancy statistics (same for men and women). Secondly, the cost of administrating the notional accounts is divided among the insured people. Finally, the growth of average income measured by the income index adjusts the account balance up- or downward. This indexation of accumulated pension wealth to average wage growth is the internal rate of return to the NDC system chosen from the Government as mentioned in Chapter 2. Since the important factor of population growth is not reflected in this indexation, an automatic balancing mechanism was introduced to ensure financial stability. This mechanism automatically adjusts the average wage indexation downwards as soon as a financial imbalance appears in the system.

At the time an individual decides to retire, the annual NDC pension is calculated by dividing the total pension balance by an annuity divisor. The annuity is determined by first dividing the account value by a unisexual life expectancy at retirement. After a cohort has reached the age of 65 life expectancy is held constant, no adjustments will be made for changes in future life expectancies. The ratio is increased by an assumed real annual return of 1.6 per cent. This assumption, made by the reformers, is based on the expected long-term real growth rate of the economy. In this way, the pensioner receives a share of future growth in advance. In the years ahead, pension benefits are indexed by the Consumer Price Index and adjusted up- or downward according to the growth of averages wages.

The guarantee pension is a top-up for everyone who has not himself managed to earn an adequate pension. To prove eligibility, the method of pension testing is used. Hence the guarantee pension is partially adjusted to take into account for other pensions from the national pension system. But it is not adjusted against occupational retirement pensions, private pensions or other earned income. The guarantee pension, disability pension, survivor pension as well as contributions for notional incomes (eg childcare, national service or students) previously financed through pay-roll taxes are now financed out of general government revenue. This change was financed by transferring an overall amount of $1 / 3$ of the balance in the buffer funds ${ }^{11}$ to the general 
budget. This decision to pay the redistributional elements out of general revenue instead of payroll taxes spreads the cost of an ageing population to a larger revenue base. This fosters the financial stability of the new Pension system.

\section{Premium-Pension}

The Premium-Pension is mandatory; individuals pay 2.5 per cent of the pension base ${ }^{12}$ to a funded individual account. Contributors can decide how the money on their accounts should be invested. Thereby savers can place funds in up to five different funds and choose among almost 700 different funds. Furthermore, PremiumPension savers can reallocate between funds on a daily basis free of charge. Contributions of savers who do not notify their choice of fund will be invested in a default fund. This fund's investment strategy mirrors the asset allocation of an average investor in the system.

The Premium Pension Authority (PPM) has been established to administer the PremiumPension accounts. This new government agency acts as a clearing house. In this function, the PPM enters into contracts with funds applying to participate in the system and buys and sells fund units at unit trust companies. Moreover, it keeps the individual accounts and collects information on fund share values and makes them available on a daily basis. ${ }^{13}$ The Swedish clearing-house model keeps administrative costs down through economies of scale and acts as a powerful buyer which can negotiate much lower administrative charges for funds than normal. ${ }^{13}$ As a result savers face two fees, first the fee of the PPM, which includes, for instance, collecting of contribution, record keeping and trading ( 0.19 per cent of assets). The second fee is the asset management fee, which is drawn by fund managers (on average 0.43 per cent of assets). These fees are rebated to the PPM according to a price-reduction model, which is a formula that makes the rebate a function of the funds normal charge and the funds holding from the PPM.

The Swedish National Social Insurance Board points out that no guarantee can be given for the development of the value of Premium-Pension money in the fund. Premium-Pension can be drawn from the age of 61 at the earliest. As an individual decides to withdraw pension, the value of the pension account is divided by an annuitisation divisor based on estimated genderneutral average life expectancy and credited with an estimated future interest rate of three per cent minus administrative costs.

\section{Assessment}

First a short review of the initial problem of the PAYG in the case of fixed contributions. As can be concluded from Equation (6), $q_{t}=\left(1+n_{t}\right) t$ declining population growth must inevitably lead to a lower replacement rate. The birth rate in Sweden was 1.76 children per women in 2004 and is assumed to increase to 1.85 in $2019 .{ }^{14}$ Under these rates, positive population growth has still not been reached. Figure 3 shows the development of the replacement rate in Sweden under the base scenario for the future. In this scenario the previously mentioned birth rates are assumed. Moreover, a real growth in average income $\left(g_{t}\right)$ of 1.8 per cent per year and a real rate of return $\left(r_{t}\right)$ on the buffer funds and the Premium-Pension is assumed to be 3.25 per cent per year. Hence the implicit rate of return $g_{t}$ on the Notional Defined Contribution account is much lower than the rate of return in the funded Premium-Pension account. As a result, the Premium-Pension accounts for a larger share of the national pension than its share of contributions. For the birth cohort 1990, the income-pension ${ }^{15}$ decreases to about 43 per cent of the average income. This decrease in the replacement rate is largely offset by an increasing share of Premium-Pensions and a prolonged working life. As a result, even the youngest birth cohort is able to secure a replacement rate of slightly above 60 per cent of average income.

Why is it that the Swedish Pension System can cope so well with an ageing population and how can it even afford a higher implicit rate of return to its NDC accounts than is normally expected in a PAYG Pension-System?

The financial stability depends to a large extent on the buffer fund, which at the end of 2005 could have financed four and a half years of pension disbursements equal to those in 2005 . 


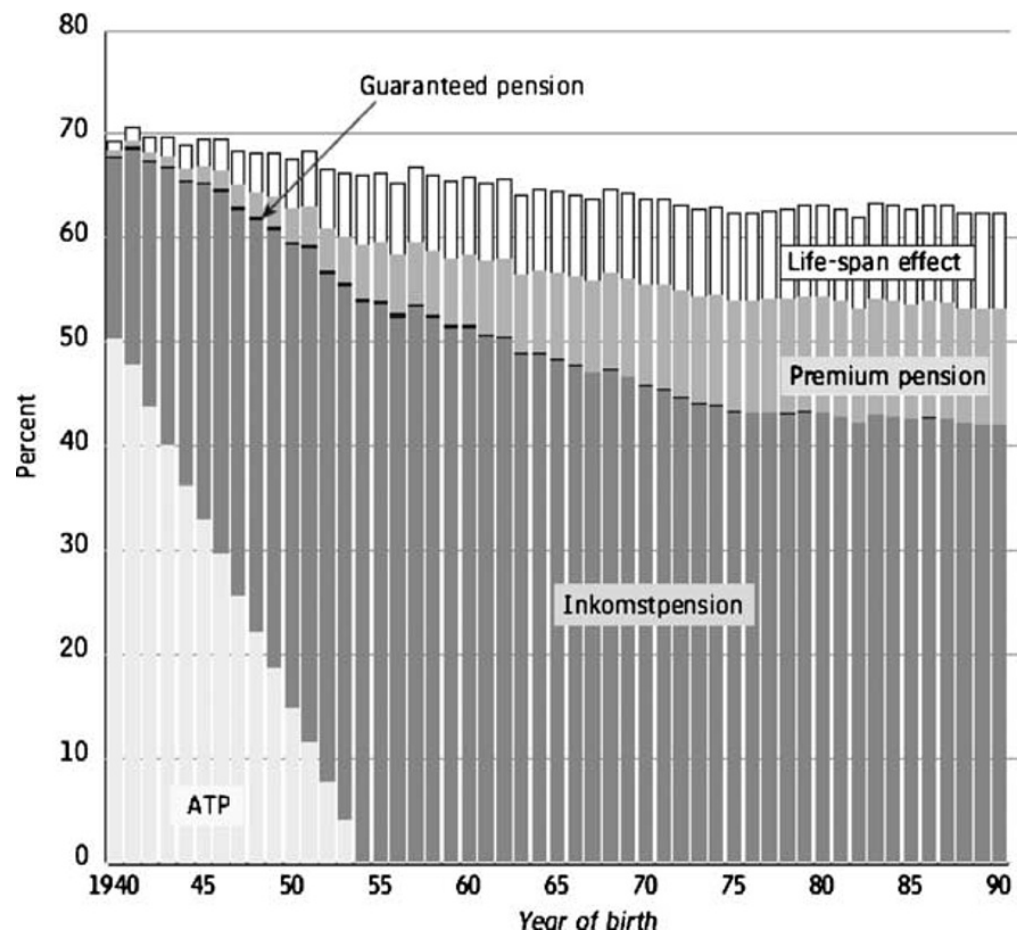

Figure 3: Average pension at age 65 as a percentage of average income, base scenario ${ }^{14}$

This fund is invested so as to achieve the highest possible return on assets and acts as a counterbalance in times of unfavourable demographic or economic development. The function of the buffer fund in maintaining financial stability can best be seen in analysing the automatic balancing mechanism of the NDC State-Pension-System. The main instrument of this mechanism is the balance ratio, which measures the financial stability of the system.

$$
\text { Balance Ratio }=\frac{\text { Contribution Asset }+ \text { Buffer Fund }}{\text { Pension Liability }}
$$

The automatic balancing mechanism will only be activated as the balance ratio falls below one. Once this occurs, two things happen. First, the implicit rate of return $g_{t}$ of earned pension will decrease to the rate of return $g_{t}$ Balance Ration. Secondly, the rate of growth used to adjust the pension benefits of retirees is also set equal to $g_{i}$ Balance Ration.

Sweden decided to use growth in average wages to index accumulated pension wealth.
Therefore, they do not account for the important factor of population growth. This shortcoming, however, is countervailed by the automatic balancing mechanism, where the growth rate of the labour force is reflected in the change of contribution asset. As assets decline due to a decreasing working population, the balancing mechanism may be activated to modify the average wage indexation as shown above.

In 2005, the buffer fund accounted for 12 per cent of the systems assets. The contribution asset consists of smoothed contribution revenue multiplied by the turnover duration ${ }^{16}$ and makes up the lion share, 88 per cent of the systems assets. Hence variations in the contribution revenue or changes in the turnover duration have a great impact on the growth of the pension system's assets. ${ }^{14}$ In each year between 2001 and 2005, the contribution asset has decreased. Nevertheless, in 2005 the system assets are slightly greater than total pension liability, with a balance ratio of 1.0044 . This outcome is attributable entirely to the high rate of return on the National Pension Funds in 2005. In Figure 4 it can be seen that not many 


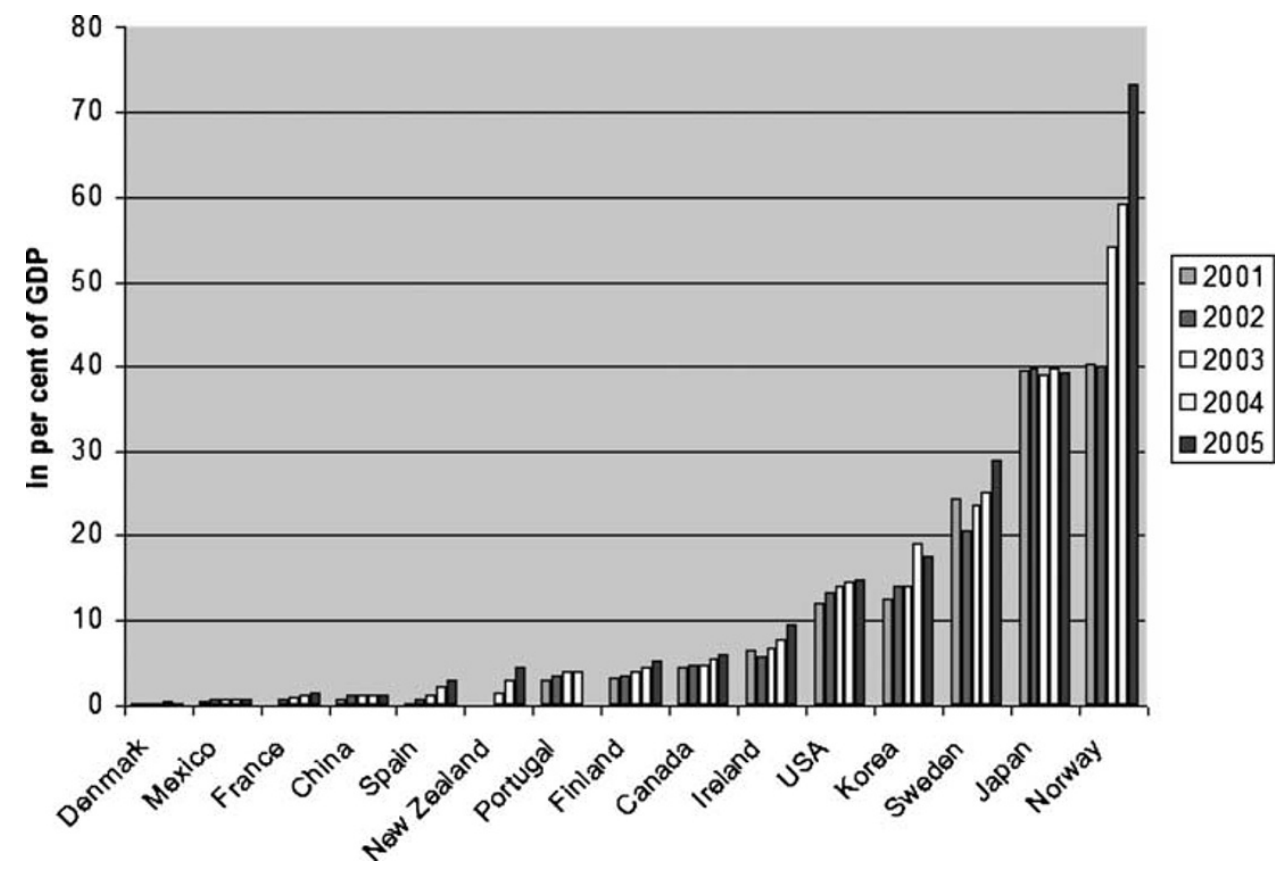

Figure 4: Pension reserve funds for selected OECD and Non-OECD member countries ${ }^{34}$

countries are in the favourable position of possessing a considerable reserve fund.

A justified critic of the automatic balancing mechanism is put forward by Alan et al. ${ }^{17}$ They ascertained that even very low values of the balance ratio would bring about relatively small reductions in the rate of growth of commitment. For example, a system with enormous liabilities might have a balance ratio very close to zero, but even in this case pension accruals would continue and a positive rate of return would be used in the computation of annuities. According to the base scenario mentioned before, the Swedish NDC Scheme is not going to face even a balance ratio less than one within the period of their forecasts. If the economic and demographic developments, however, deviate from the base scenario, the balance mechanism is not far from being activated since the balance ratio is already close to one.

The annuity divisor is calculated from the mortality risks based on observations over the latest five-year period and is fixed after a cohort has reached the age of 65 . This means that pension payments will not be adjusted as the life expectancy increases. Hence the increased pension liability negatively affects the balance ratio. This deficiency of the NDC System is also acknowledged in The Swedish Pension System Annual Report. ${ }^{14}$ Furthermore, the report for the first time assesses the consequences of repeated increases of the basic deduction, that is, the minimum income that must be declared to the tax authority. All income below the basic deduction is excluded from the measure of income. This means fewer persons are included in the calculation of average income. Since the persons no longer included earn low incomes, the implicit rate of return of the NDC System rises. This increase in pension liability is not matched by a similar increase in contributions that leads to a decrease in the balance ratio. The pension system shall become autonomous and bear its own costs entirely. In 2005, 68 per cent of the cost of administration was financed by deductions from pension balances. The rest was financed out of the buffer fund. It is not until 2021, when administration costs will fully be financed through deductions from pension balances and the buffer fund will be relieved from these costs. ${ }^{14}$

To conclude, a lot of imperfection in the system can be absorbed through the buffer fund and the rent on it. Nevertheless, the return on 
the buffer fund is affected by the development of equity market, where share prices vary considerably from year to year. Hence negative developments in the equity market may cause the activation of the balancing mechanism. Even that would not, however, lead to financial instability of the system. It only implies that the implicit rate of return, which is the average wage growth, decreases and thus comes closer to the traditional growth rate of a PAYG System, the growth in the total wage bill.

\section{The state pension system in Germany}

\section{Features of the pension system today}

The German pension system consists of three pillars, the PAYG-financed state pension, subsidised and funded 'Riester contracts' either as an occupational or private scheme and other kinds of private saving. Occupational pension schemes were not widespread in Germany, until the 'Riester reform' 2001, named after the then labour minister Walter Riester, made them more popular. The number of people covered from occupational pension schemes in the private sector increased from 29 per cent in $2001^{18}$ to 46 per cent in 2004. ${ }^{19}$ This reform introduced subsidies or tax relief on contributions, if workers were contributing a certain amount of their gross income to a supplementary pension scheme.

\section{PAYG}

The pay-as-you-go pillar of the German pension system is the most important part of the old age insurance and according to the responsible ministry this shall not change in the future. Almost three quarters of total old-age and survivor's pensions are PAYG financed (Figure 5). ${ }^{20}$

Until the 'Riester reform' in 2001 pensioners enjoyed a fixed replacement rate of 70 per cent. ${ }^{21}$ This high rate was unsustainable because of a slow down of the economy accompanied by high rates of unemployment and an ageing population. The burden of this destiny had fully been borne by the working generation in the form of ever increasing pay-roll taxes. At present, the pay-roll tax amounts to 19.5 per cent of income, up to a

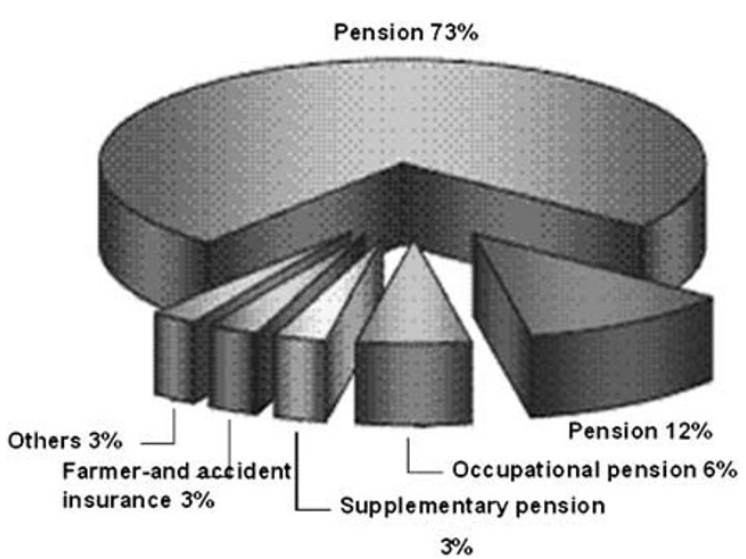

Figure 5: Old-Age-Insurance in Germany $2003^{19}$

ceiling. This contribution is equally shared between employer and employee. With the major objective to stabilise contribution rates and to share the burden more equally between the generations, the government changed the pension formula. This formula defines the monthly pension during retirement.

Three factors of the formula have the purpose of calculating the individual pension balance of the insured person and a fourth factor determines the internal rate of return of the pension system. ${ }^{22}$ The first element, which contributes to the pension balance, ensures a close link between contributions and pensions by assigning earning points. Individuals acquire more earning points, the higher the income and the more years they remain employed. The second element of the pension balance adjusts the balance downwards if someone retires before the statutory pension age of 65 and upwards if someone retires later. This measure increases work incentives since working longer does not only increase future pensions through more earning points but also increases retirement benefits by 0.5 per cent for each month of postponing the retirement age. The last factor affecting the pension base is only relevant if the beneficiary dies, then it transfers a part of the pension rights to the widow or surviving children. With this derivation of the pension base redistribution in the pension system is quite small and thus the pension scheme provides a strong 


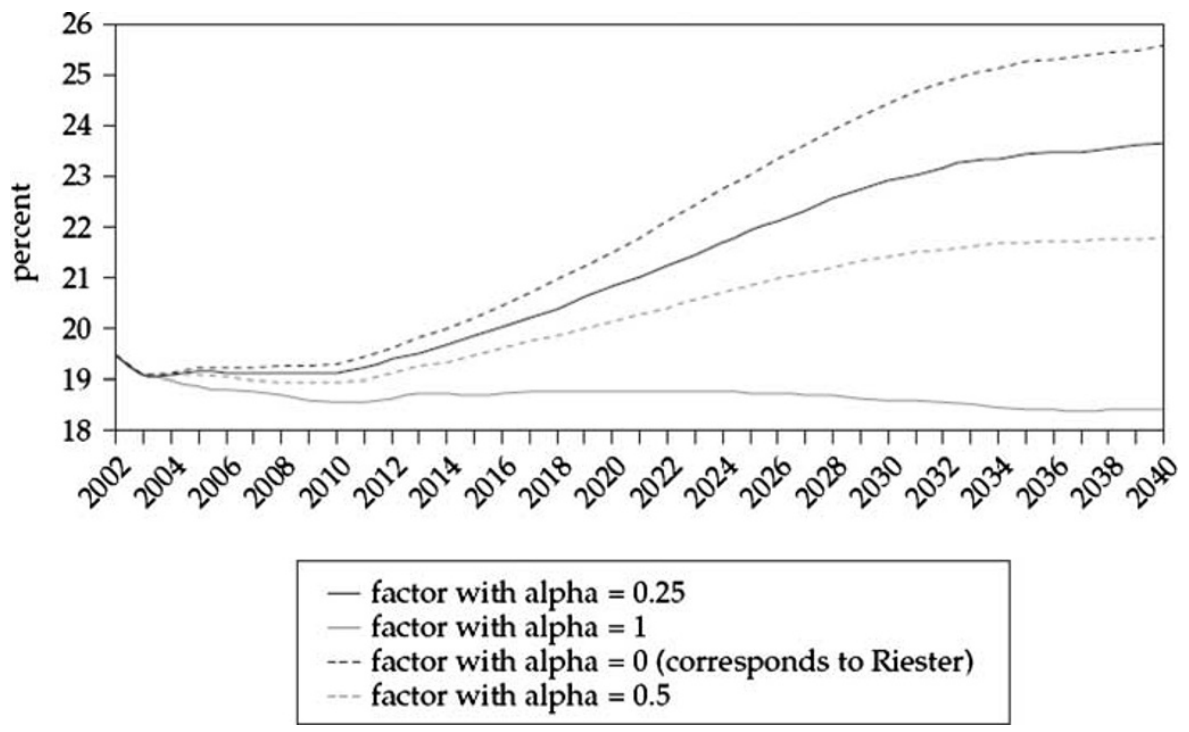

Figure 6: The effects of the sustainability factor on the development of contribution rates ${ }^{35}$

actuarial link between lifetime income and pension benefits.

The fourth factor is called the current pension value and determines the internal rate of return of the pension system. Simplified, this factor can be explained as taking into account changes of gross income net of contributions to the pension system as well as demographic developments and developments on the labour market. This indexation factor comes close to the implicit rate of return in the PAYG system of Chapter 2. The demographic element in the German pension formula is called the sustainability factor and was introduced in 2004. Since the sustainability factor enters the pension formula as a weighted factor it also affects the income distribution between current workers and pensioners. As the weight on this factor increases, the risk of ageing will be shifted more towards pensioners. Figure 6 reflects this scenario by showing how the contribution rates increase less as the weight (alpha) on the demographic factor increases. As a result, the pensioners face decreasing replacement rates.

Currently the weight is 0.25 , it is determined so as to fulfil the two targets of the Pensions Insurance Sustainability Act 2004. First, the contributions rate shall not exceed 20 per cent until 2020 and 22 per cent until 2030 and secondly the replacement rate shall not be lower than 46 per cent until 2020 and 43 per cent until 2030. While it is at the moment 53 per cent, these percentages seem a little bit weird, when compared to the previous fixed replacement rate of 70 per cent. Fortunately, these percentages can easily be explained by a change in defining the replacement rate. The Old-Age Income Act 2005 initiated the transition to downstream taxation of old-age income and towards tax-free pension expenditure. This measure frees money, which the working generation can use to build up additional occupational or private pension. The stepwise introduction of downstream taxation would make a comparison of replacement rates for new retirees impossible. Hence instead of dividing the pension of a worker, who had 45 earnings points $^{23}$ by the average net earnings of all current workers, it is now divided by the gross earnings.

\section{Riester pension}

Changes in the pension formula entailed a pension gap created by a declining replacement rate. To compensate losses of retirement income, a new funded pillar was introduced. The Government decided to leave the decision to invest in a supplementary pension scheme to the individual. Nevertheless, the state is ambitious to persuade people to save if they want to sustain their standard of living during retirement. To 
increase the acceptance of the new scheme, the state created incentives in the form of direct saving subsidies or tax-deductible special allowances. The tax authorities automatically compute which of the two incentives is most advantageous to the saver. In 2008 the scheme will be fully implemented. At that time people will have to save at least 4 per cent inclusive state benefit of their gross-yearly-income to be entitled to full benefits. Beneficiary's can also decide to save less, then government benefits will be adjusted accordingly. A full benefit amounts to 154 euros plus 185 euros per child. People on low income are entitled to full subsidies if they contribute 60 euros themselves. Occupational pension schemes have to fulfil moderate requirements to participate in this scheme. But private retirement accounts have to fulfil a list of criteria in order to qualify for state promotion. These accounts must for example ensure a constant or increasing life-long monthly annuity based on unisex tariffs. Moreover at the beginning of the payment stage, at least the amounts that have been paid (individual contributions and allowances) must be guaranteed by the provider. ${ }^{24}$ At the age of 60 , savers can decide to withdraw annuities. In 2001, when the Riester Pension was introduced $1.4 \mathrm{~m}$ people decided to save in a supplementary pension scheme. The number of participants increased to 6.4 million in $2006 .^{25}$ This is still not everyone who is entitled to a subsidised pension account and until everyone takes advantage of the Riester Promotion it may take several years. This could be too late for many people in the light of a declining replacement rate in the PAYG scheme. Everyone who has not earned sufficient pension rights at the age of 65 is entitled to a means tested minimum pension.

\section{Assessment}

Again a short review of the initial problem of the PAYG. Since the introduction of the sustainability factor, which increasingly leads to reductions in the replacement rate, Germany comes closer to a fixed contributions approach. In this case, it can be concluded from Equation (6), $q_{t}=\left(1+n_{t}\right) t$ that declining population growth must inevitably lead to a lower replacement rate. In Germany, the situation is even worse than in Sweden. The fertility rate lies by 1.4 children per women and the unemployment rate is one of the highest in Europe. Moreover, the national financial situation is disastrous, several times in a row Germany was not able to adhere to the EU 'Stability and Growth Pact'. Nevertheless, the government subsidies to the pension system amount to about $1 / 3$ of total expenditure. This yearly subsidy is financed out of general revenue and to some extent from ecology tax. Part of this subsidy is used for redistribution measures that can be regarded as a task for society as a whole, but the remaining part is needed to keep contribution rates down and pensions above a certain level. When countries like the Netherlands and France started to build up pension reserve funds in order to maintain adequate pension provision for the retirement of the 'baby-boom' generation, Germany continually decreased its reserve from 1 to now 0.2 month worth of pension payments. This is thought to be sufficient to balance fluctuating contributions. Should the pension reserve fall below 0.2 months worth of pensions or increase above 1.5 worth of monthly pension expenditure, the contribution rate had to be adjusted accordingly. According to a model calculation, the Government is likely to support the pension system with a one-off payment in 2008 to keep contribution rate at 19.9 until 2009 and to avoid pension cuts. ${ }^{26}$ As a result, the rule above becomes negligible and the low reserve can have profound consequences on the financial stability of the pension system, when it comes to the retirement of the 'baby-boom' generation.

This year the Government legislated the increase of the retirement age to 67 , as suggested by the 'Rürup Commission' 2004. For this measure to be implemented fully, they chose a transition period from 2012 to 2023 with yearly increases in the retirement age. This is accompanied with increased efforts to improve the situation in the labour market for older citizens. Figure 7 is a projection of the development in the pension level after the reforms that were described earlier. Individuals between 2004 and 2013 will find themselves in a pension gap. For them the reforms came too late 


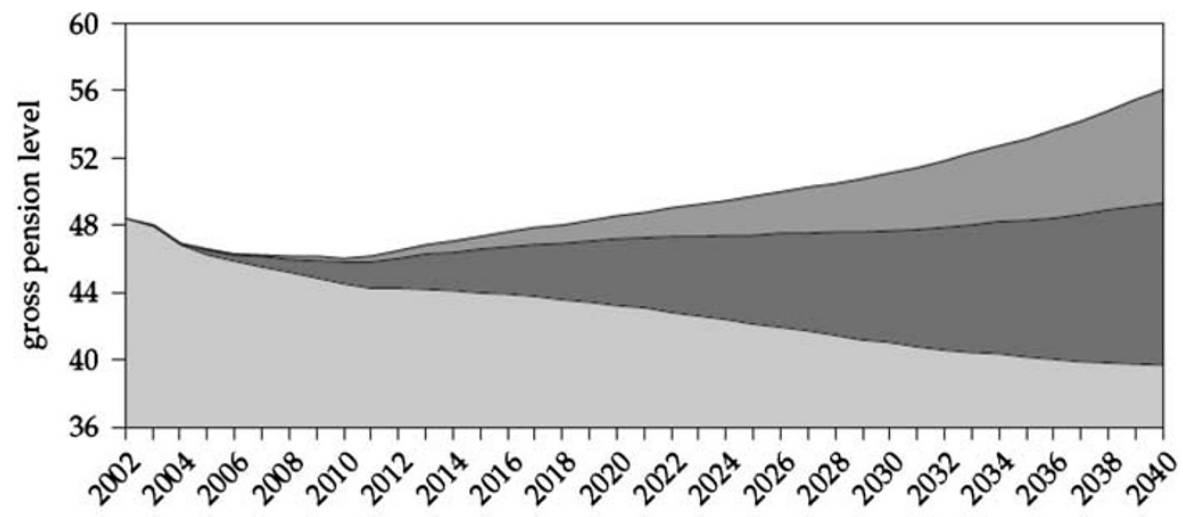

$$
\begin{aligned}
& \square \text { Riester pension at a nominal interest rate of } 6 \text { percent } \\
& \square \text { Riester pension at a nominal interest rate of } 4 \text { percent } \\
& \square \text { level of statutory pensions after an increase in the normal } \\
& \text { retirement age and the implementation of the sustainability factor }
\end{aligned}
$$

Figure 7: Total pension level including private riester pensions ${ }^{35}$

to build up private savings in order to adjust for a decreasing pension level. In 2003 an almost means-tested guaranteed benefit was introduced to secure a minimum standard of living for people from the age of 65 . The working population is assumed to contribute four per cent, including the state subsidy, of gross yearly income to a supplementary private Riester Pension Scheme from 2008 on. Since participation is voluntary, not everyone is using this option to secure a decent pension when retiring. Hence it could take more time than expected until people make use of this option. The Government may need to start additional information campaigns especially for people on low income or to make participation mandatory.

The final implementation of the sustainability factor into the pension formula in 2004 leads to an implicit rate of return, which comes close to the outcome in the second section of this paper. The internal rate of return for a PAYG system equals the rate of growth of the labour force $\left(n_{t}\right)$ plus the rate of growth of output $\left(g_{t}\right)$. The new factor accounts for the demographic development as well as the development on the labour market. Hence the indexation of pensions would reflect changes in the economic environment fairly well if the Government did not legislate a clause to safeguard pension levels. ${ }^{27}$ This clause prevents pensions from declining, by assuming a zero rate of return when it actually is negative. In 2005, the negative effect of the contribution rate and the sustainability factor $\left(n_{t}\right)$ was greater than the positive effect of wage growth $\left(g_{t}\right)$ from 2003 to 2004 , which would have led to a negative rate of return and hence to a reduction in pensions. ${ }^{24}$ The Government plans to postpone such reductions to periods of positive internal rents. This approach is open to critic because it does not reflect the underlying economic and demographic developments. While the working generation faces a decline in their purchasing power, the retiree's standard of living remains unaffected.

The German PAYG System is far from financial stability and continuously seeking possibilities to slow down rising expenditures. Some examples for recent saving measures are cancelling of pension credits for schooling and university, full contributions to nursing care insurance for pensioners, organisational reform of pension authority, the payment date for contributions is now one month earlier, which led to an increase in contributions and abolishing of contribution-free night shift and public holiday premium. 


\section{Conclusion}

First, it has to be mentioned that both countries had to reform their pension system under different preconditions. In the years 1991 until 2003, the labour force participation rate of the 15-64 years old was constantly at least five percentage points higher in Sweden and the participation rate of the 55-64 years old even exceeded Germany's by more than 20 percentage points. ${ }^{28}$ Another important difference is the financial situation of the pension system before the reform. The Swedish Government was in the advantage of being able to transfer a substantial accumulated reserve from the old to the new system. Part of the money was used to provide compensation for the transition costs. The remaining part of the buffer fund was calculated to be sufficient to avoid the balance ratio dropping below one in any year during that time. Germany's reserve today and in the past is not worth mentioning.

Both systems, however, can be criticised of not allocating the burden of an ageing society equally between generations. In Sweden, a negative development of the total wage bill will never lead to a decline in pensions since the balance ratio can never become negative. The pension security act in Germany does not allow pensions to decline, which undermines the stabilising effect of the sustainability factor. The Swedish buffer fund's purpose is also to finance the retirement of the 'baby boom' generation. As this huge cohort starts to retire I expect, against the projections of the strategy report, an activation of the balancing mechanism since the balance ratio is already close to one. At that time it will be increasingly difficult to counterbalance all the small imperfections of the Swedish NDC system, which were previously compensated by returns on the buffer fund. I do not, however, worry about the long-term financial stability of the Swedish pension system, it will recover soon, thanks to the stable economic environment created to a large extent through policy measures of the government.

A greater problem has to be faced by Germany, the pension system seems completely unprepared to cope with increasing expenditures caused by the retiring 'baby-boom' generation. Greater state subsidies will be needed and the Government should think about making the supplementary pension mandatory as soon as possible because it will take too much time until it is fully taken up by the population. And time already has expired for many people finding themselves in the pension gap. ${ }^{29}$ Projections of the Swedish and German pension system show that the introduction of a funded pillar into the pension system has been an effective way for the population to offset decreases in their pension levels.

To conclude, I would like to point out that the stability of a pension system also very much relies on its acceptance in the population. In this aspect Settergren ${ }^{30}$ points out four focal points; explain the new system, harmonise the expectations of the insured with the economic and demographic realities, improve the insured's opportunities for well-informed decisions and create a relevant sense of confidence and trust between the system and the insured.

\section{References}

1 Sundén, A. (2004) 'The future of retirement in Sweden.' Pension Research Council Working Paper, The Wharton School, University of Pennsylvania.

2 Economic changes would include, for instance, fluctuations of rate of productivity growth and the interest rates (interest rates do not matter in a pure pay-as-you-go system but in the Swedish NDC version of it).

3 Homburg, S. (1988) 'Theorie der Alterssicherung', Springer-Verlag, Berlin-Heidelberg.

4 Which might not be true for Germany, because 2005 almost $1 / 3$ of the pensions were paid out of general revenue.

$5 n_{t}=N_{t}^{1}-\mathrm{N}_{t-1}^{1} / \mathrm{N}_{t-1}^{1}$ can be written as $n_{t}=N_{t}^{1} / \mathrm{N}_{t-1}^{1}-\mathrm{N}_{t-1}^{1} / \mathrm{N}_{t-1}^{1}$ hence $N_{t}^{1} / \mathrm{N}_{t-1}^{1}=1+n_{t}$ which can be substituted for $N_{t}^{1} / N_{t}^{2}$.

6 Fenge, R. and Weizäcker, J. (2006) 'Generation Enkellos und Rentenbeitragsrabatt für Eltern', Ifo Schnelldienst, Vol. 59, No. 5, pp. 11-18 (Ifo Institut für Wirtschaftsforschung, München).

7 Accounts for the quotient of pensioners and contributors in the pay-as-you-go-system.

8 Saving for own pension and paying the pension of the retirees.

9 For definition see Appendix A.

10 Regeringskansliet (2005) The Swedish National Strategy Report on Adequate and Sustainable Pension 2005 [online]. [cited 25 October, 2006]; Available from: URL: http://ec.europa.eu/ employment_social/social_protection/docs/2005/sv_en.pdf.

11 Pension reserve fund.

12 For definition see Appendix A.

13 Klevmarken, N. (2002) Swedish pension reforms in the $1990 \mathrm{~s}$ Paper prepared for the Foundation Ramon Areces conference on Pensions in Europe. Madrid 2002.

14 Settergren, O. (2005) 'The Swedish Pension System Annual Report 2005', Swedish Social Insurance Agency, Stockholm. 
15 Pension from NDC is called income-pension.

16 For definition see Appendix A.

17 Auerbach, A. J. and Lee, R. (2006) 'Notional defined contribution pension systems in a stochastic context: Design and stability', NBER Working Paper No. 12805.

18 Federal Statistical Office Germany (n.d.).

19 German Federal Ministry of Labour and Social Affairs (2005) 'Alterssicherungsbericht 2005', [online], [cited 10 May, 2007]; Available from http://www.bmas.bund.de/BMAS/Redaktion/ Pdf/Publikationen/alterssicherungsbericht-2005-langfassung, property $=$ pdf, bereich $=$ bmas, sprache $=$ de, $r w b=$ true. $p d f$.

20 Pension 12 per cent, are pensions especially for civil servants.

21 See definition for replacement rate before 2005.

22 Explicit formula see Appendix C.

2345 earnings points refers to a person who earned the average wage during his 45 years working life.

24 German Federal Ministry of Health and Social Security (2005) National Strategy Report on Old-Age Pension Provision 2005.

25 German Federal Ministry of Labour and Social Affairs. Information about the German Pension System [online]. [cited 2006 Oct 25]; Available from: URL: http://www.bmas.bund.de/ BMAS/Navigation/rente.html.

26 German Federal Ministry of Labour and Social Affairs (2005) 'Rentenversicherungsbericht 2005', [online], [cited 10 May, 2007];
Available from http://www.bundesregierung.de/Content/DE/ PeriodischerBericht/Berichte-der-Bundesregierung/2006/03/_Anlagen/ rentenversicherungsbericht-2005978278, property=publicationFile.pdf.

27 'Sozialgesetzbuch VI' 2004, \$68.

28 Eurostat. Datenbank NewCronsos. Luxembourg, 2004.

29 See Figure 7.

30 Settergren, O. (2004) Lessons from the Great Swedish Pension Reform (Powerpoint). Swedish Social Insurance Administration, 2004.

31 Definitions $1-5$ by John B. Williamson, An issue in brief center for retirement research at Boston College October 2004, no. 24, Assessing the notional defined contribution model.

32 Bundesagentur für Arbeit (2005) Data on pay-roll taxes, 2004 and VDR. Data on jobs subject to social insurance contributions.

33 Deutsches Institut für Altersvorsorge [online], [cited 25 October, 2006]; Available from http://www.dia-vorsorge.de/df_050321.htm.

34 OECD Global Pension Statistics [online] (2006) [cited 18 April, 2007]; Available from URL: http://www.oecd.org/document/ 46/0,2340,en_2649_34489_36091822_1_1_1_1,00.html.

35 MEA calculations based on the Rürup Commission's demography and labour market projections cited in BörschSupan, A. H. and Wilke, C. B. (2005) 'The German public pension system: how it will become an NDC system look-alike', in Holzmann, R. and Palmer, E. (eds.) 'Pension Reform-Issues and Prospects for Non-Financial Defined Contribution (NDC) Schemes', World Bank: Washington, DC, pp. 573-610.

\title{
Appendix A
}

\author{
Definitions $^{31}$
}

Defined benefit approach

Defined contribution approach

Pay-as-you-go

Funded pension

Notional defined contribution Downstream taxation

Pension-qualifying incomes

Pension-qualifying amounts ${ }^{s}$

Pension credits

Pension balance ${ }^{a}$

Pension base ${ }^{a}$ benefits are based on a formula that relies on how much workers make and how long they work

benefits are typically determined by the amount contributed and the accumulated earnings on those contributions

contributions from current workers and their employers are used to pay the pensions of current retirees

contributions are invested in individual accounts that are used by workers to pay for their own retirement benefits

a defined contribution model with individual accounts financed on a pay-as-you-go basis old-age income is not taxed until pensions are received in old age. In return contributions to pensions in the working phase remain untaxed up to a maximum annual amount.

the income which together with pension-qualifying amounts is used to calculate the pension credit of the insured. In principle, pension-qualifying income consists of annual income (earnings, sickness cash benefits, parental cash benefits, unemployment cash benefits, etc.) reduced by the individual pension contribution.

a basis for pension credit not related to actual earned income. Pension - qualifying amounts may be credited for sickness and activity compensation, care of small children, study, and compulsory national service

an individual's pension credit is 18.5 per cent of his total pension base and equal to his total pension contribution. Individuals born in 1954 or thereafter are credited with 16 per cent of their pension base for the income-pension and with 2.5 per cent of their pension base for the premium pension. Pension credit increases the individual's pension balance and premium-pension capital.

the total confirmed pension credit for the income-pension, recalculated annually in accordance with the income index, inheritance gains and the cost-of-administration factor.

the total of an individual's pension-qualifying income and pension qualifying amounts, but only up to a ceiling. 


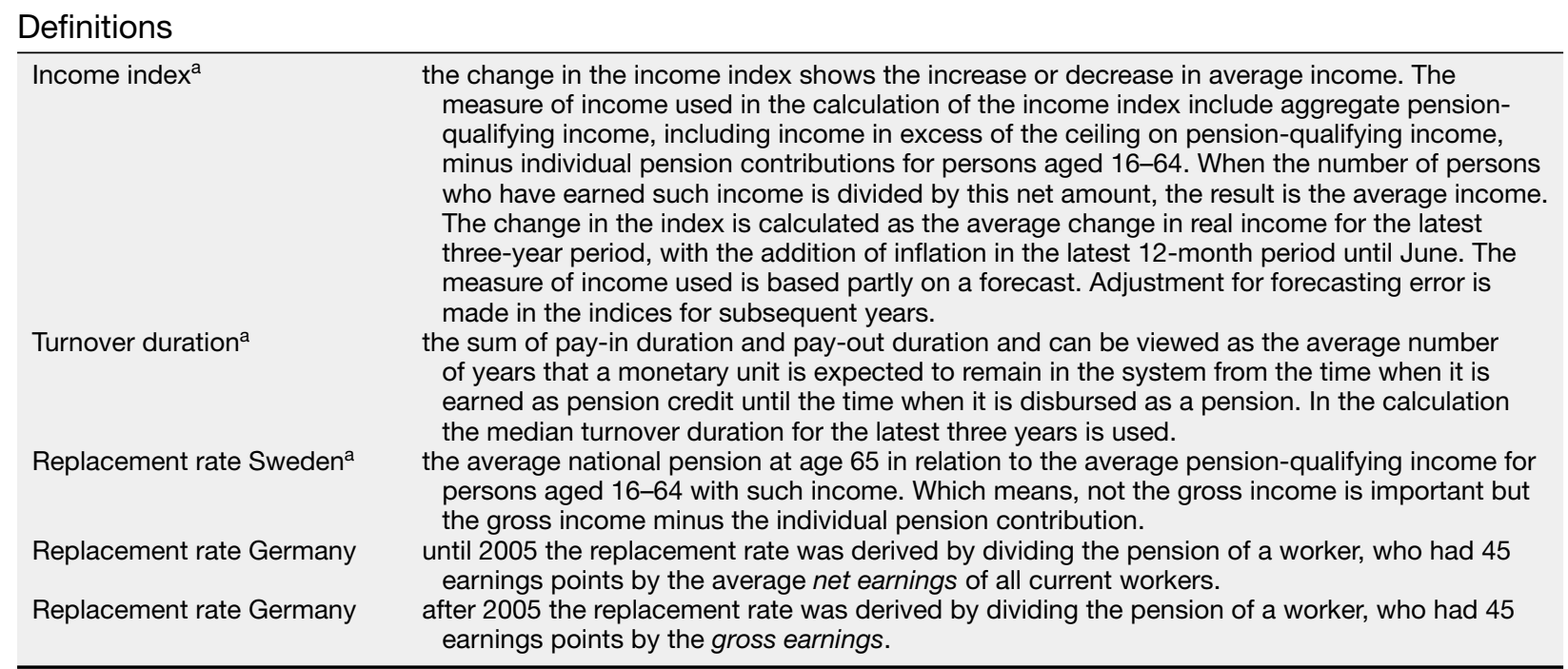

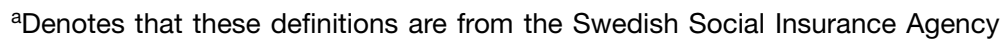

\section{Appendix B}

\section{Notations}

$N_{t}^{1}$
$N_{t}^{2}$
$n_{t}=N_{t}^{1}-N_{t-1}^{1} / N_{t-1}^{1}$
$g_{t}=w_{t}-w_{t-1} / w_{t-1}$
$t_{t}$
$P_{t}$
$q_{t}$
$i_{t}$

\section{Appendix C}

\section{Formulas (German Federal Ministry of Labour and Social Affairs 2006)}

This formula defines the monthly pension during retirement

$$
P=E P \cdot S Y \cdot A F \cdot P V
$$

labour force in period $t$ pensioners in period $t$ growth rate of the labour force growth of the wage rate pay-roll tax (contribution rate to the PAYG) pension in period $t$ replacement rate in period $t$ internal rent in period $t$ in a PAYG System

\section{Earning points (EP)}

During a working history an individual can acquire earning points after the following method:

$$
E P_{i}=\frac{\text { individual average gross wage year } i}{\text { average gross wage year } i}
$$

At retirement all earning points are summed up and included in the pension formula.

\section{Years of service life (SY)}

It contains years of active contributions but also time without any contribution. This could be for example years for child-care, military service or unemployment. At the time the retirement age in Germany is 65 , which equals an SY of 1 . Each month an individual decides to retire earlier, the SY will be reduced by 0.3 per cent and each month of postponing retirement leads to an increase of 0.5 per cent. Hence the decision to retire at the age of 66 leads to an SY of 1.06 $(1+0.005 \times 12)$.

\section{Adjustment factors (AF)}

This factor is 1 for a normal old-age pension, 0.55 for widow pension and 0.2 for surviving children ('Vollwaisenrente'). 


\section{Current pension value}

$$
\begin{aligned}
P V_{t}= & P V_{t-1} \cdot \frac{A G I_{t-1}}{A G I_{t-2}} \cdot \frac{\left(100-t_{t-1}-A V A_{t-1}\right)}{\left(100-t_{t-2}-A V A_{t-2}\right)} \\
& \times\left(\left(1-\frac{P Q_{t-1}}{P Q_{t-2}}\right) \cdot \alpha+1\right)
\end{aligned}
$$

(Pensions Insurance Sustainability Act 2004, \$68) The current pension value relates the changes in the pension value to lagged changes in gross income $\left(\mathrm{AGI}_{t}\right)$, modified by the actual contribution rate to public pensions $\left(t_{t}\right)$ and a fictitious contribution rate to the new private pension accounts $\left(\mathrm{AVA}_{t}\right)$. This component will increase from 0.5 per cent in 2003 to 4 per cent in 2009. The new sustainability factor, in inner brackets, reflects the development of the relative number of contributors to pensioners. ${ }^{17}$

$$
P Q=\frac{\text { pensioners }}{\text { contributors }+ \text { unemployed }}=\text { dependency ratio }
$$

$\alpha$ is the weight of the sustainability factor, which determines the financial distribution of the burden created by an increasing dependency ratio. $\alpha$ was set to $1 / 4$ to achieve the following targets: The contributions rate shall not exceed 20 per cent until 2020 and 22 per cent until 2030 and the replacement rate shall not be lower than 46 per cent until 2020 and 43 per cent until 2030. 